\title{
Osteosarkoma pediatrikoarekiko suszeptibilitatean inplikatuta dauden aldaera genetikoak
}

\author{
(Genetic polymorphisms implicated \\ in pediatric osteosarcoma)
}

\author{
Nerea Bilbao-Aldaiturriaga ${ }^{1 *}$, Ángela Gutierrez-Camino ${ }^{1}$, \\ África García-Orad ${ }^{1,2}$, Idoia Martin-Guerrero ${ }^{1,2}$ \\ ${ }^{1}$ Genetika, Antropologia Fisikoa eta Animali Fisiologia saila, Medikuntza \\ eta Erizaintza Fakultatea (UPV/EHU) \\ ${ }^{2}$ BioCruces Health Research Institute \\ * Instituto Ginecológico y de Reprodución Asistida iGin S.L.P \\ idoia.marting@ehu.eus
}

DOI: $10.1387 /$ ekaia.17896

Laburpena: Osteosarkoma (OS) edo sarkoma osteogenikoa gazteen artean gertatzen den hezur-minbizirik ohikoena da. Adin hain goiztiarretan sortzeak adierazten du haren jatorrian genetikak paper garrantzitsua duela. Izan ere, hainbat ikerketa-lanen arabera, sarkortasun txikiko aldaera genetikoak (SNPak, esaterako) OSaren kausa izan ohi dira. Jakina da beste minbizi mota batzuetan aldaera genetikoek gaixotasun horrekiko suszeptibilitatean eragina izaten dutela. miRNAk dira minbizien jatorri eta bilakaeran gehien aztertu diren RNA ez-kodetzaileak (ncRNA). Hori dela eta, bai gune kodetzaileetan bai ez-kodetzaileetan (miRNAk eta hauek prozesatzen dituzten geneak) zen aldakortasun genetikoa aztertu genuen. Lan honetan, OSarekiko suszeptibilitatean eragina duten aldaera genetikoen bilaketa egin genuen. Gure emaitzek CTLA4 genea eta 14q32 guneko miRNA taldeak OSarekiko suszeptibilitatearen hotspot-ak izan daitezkeela erakusten dute.

Hitz gakoak: osteosakoma, SNP, suszeptibilitatea eta miRNA.

Abstract: Osteosarcoma (OS) is the most common primary bone cancer that occurs primarily in children, adolescents, and young adults. The fact that OS occurs at an early age suggests that there is a strong genetic component at its source. Several studies have suggested that susceptibility to OS development is due to small common low-pene- 
Nerea Bilbao-Aldaiturriaga, Ángela Gutierrez-Camino, África GarcíaOrad, Idoia Martin-Guerrero

trance variants, such as SNPs. The implication of the common genetic variants in the susceptibility to cancer has already been demonstrated in several studies. One of the most non-coding RNAs studied in cancer are miRNAs and are known to be involved in the origin and evolution of various cancers. Therefore, we analyzed all the genetic variability of the genes of the miRNAs processing path and their implication in the susceptibility of the OS. As a result, we decided to validate the association between the genetic variants previously associated with the risk to develop OS and to look for new risk markers in the genes related to the miRNAs. Our results indicated that a SNP in the CTLA4 gene could be a marker of susceptibility to develop OS along with the hotspot in the $14 \mathrm{q} 32$ region.

Keywords: osteosarcoma, SNP, susceptibility and miRNA.

\section{SARRERA}

Osteosarkoma (OS) edo sarkoma osteogenikoa lehen mailako hezurminbizirik arruntena da, \%20ko maiztasuna baitu lehen mailako minbizien artean $[1,2]$. Hezur-muinean sortzen den tumorea da; haren zelula neoplasikoek hezur-ehuna suntsitzen dute, eta osteoidea deritzon heldugabeko hezurra eragiten[3].
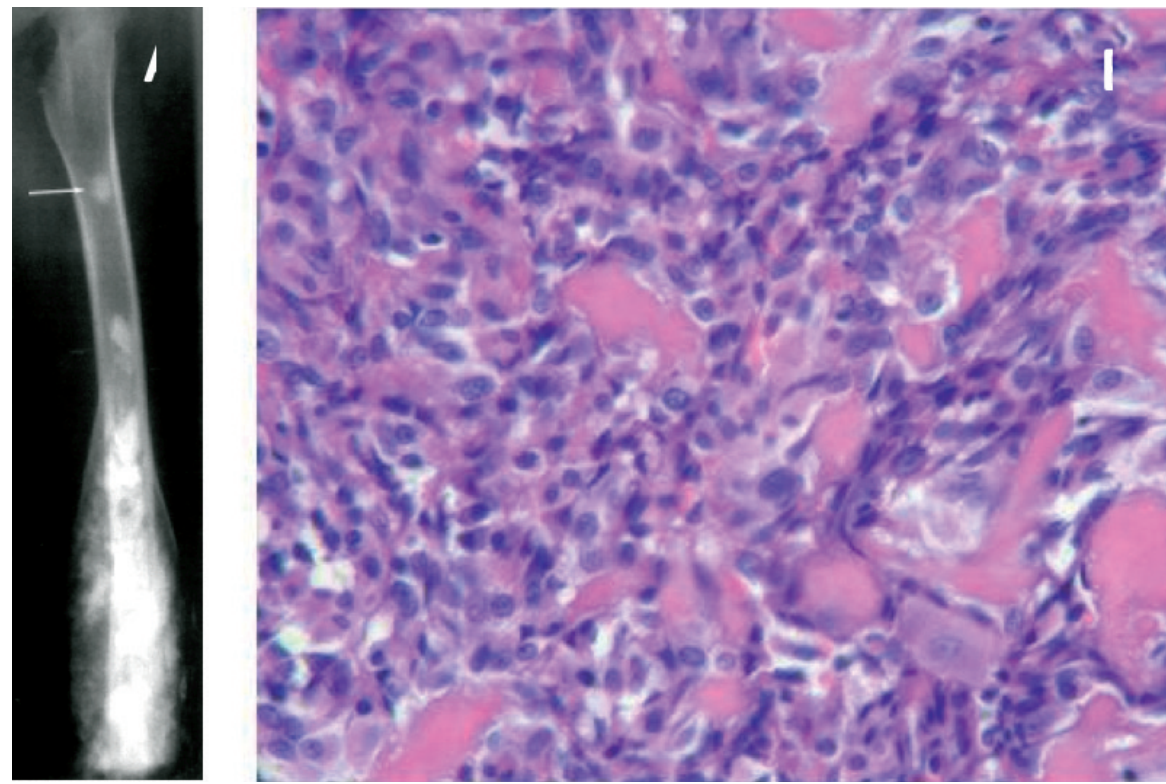

1. irudia. A) Femurraren OSaren erradiografia [3]. B) Nukleoaren itxura atipikoa eta osteoidea ekoizten duten zelula fusiforme anitzen populazio-tindaketa eosinofiloan [4]. 


\subsection{Etiologia}

Zenbait arrisku-faktore deskribatu dira OSaren jatorrian: ingurune-faktoreak (aldez aurretiko trauma, erradioterapia edo kimioterapia jaso izana, eta hezur-lesio onberak) eta faktore genetikoak (heredatutako mutazioak eta somatikoak).

OS azkar berriztatzen diren hezur-ehunetan maiz agertzen da. Gune hauetan, hezur- eta kartilago-zelulak zelula ama mesenkimaletatik (ZAM) azkar desberditzen dira; hori dela eta, mutazioak gertatzeko joera dagoenez, desberdindu, eta zelula ama tumoral (ZAT) bilakatuko dira [5].

Gaur egun, bi teoria daude OSaren sorrera azaltzeko. Lehengo teoriaren arabera, osteoblasto aitzindaritik heldurako desberdintze-prozesuko urratsetan mutazioak gertatzen dira [6]. Prozesu honetan, mutazio-urratsetatik azpimota histologikoak etorriko lirateke (kondroblastoa, fibroblastoa eta osteoblastikoa). Bigarren teoriak dioenez, mutazioak osteoblasto aitzindarian gertatuko lirateke eta, ondorioz, azpimota histologiko guztiak aitzindari honetatik eratorriko lirateke [7] (2. irudia).

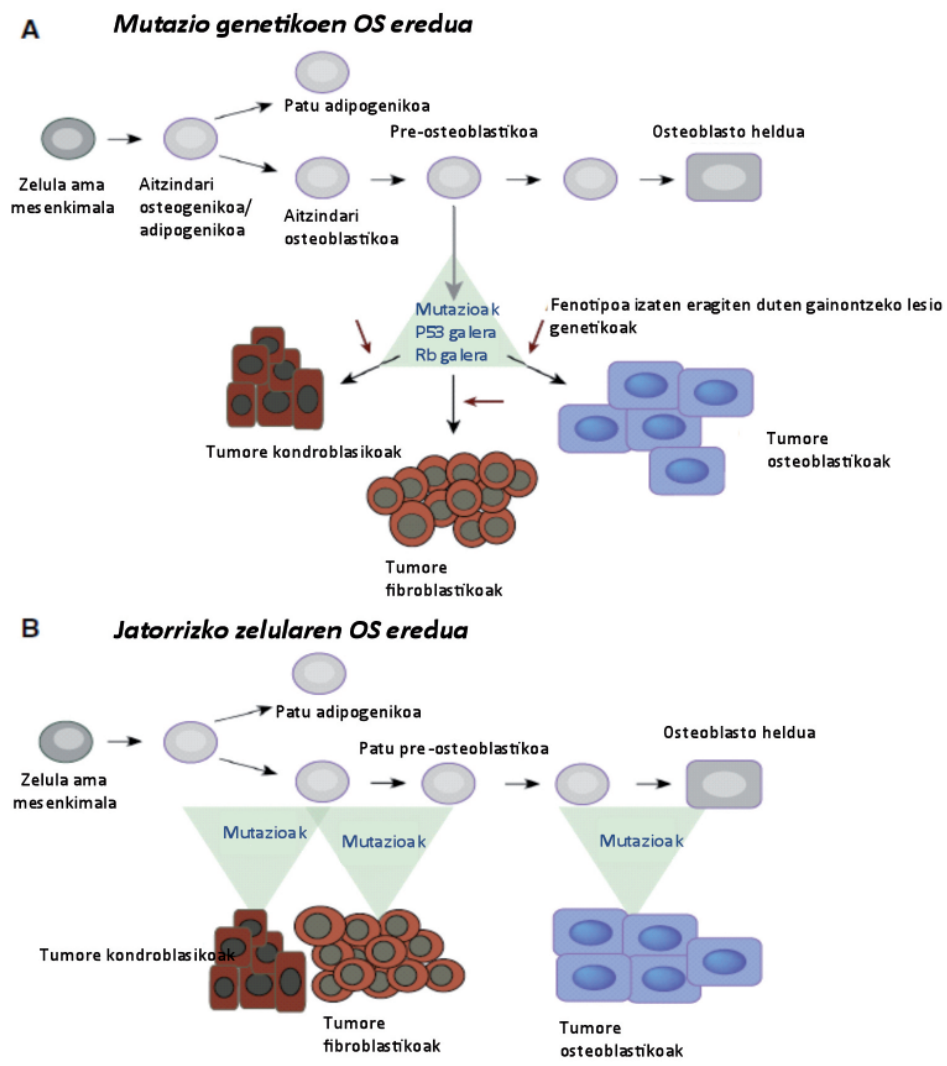

2. irudia. OSaren sorrera azaltzeko teoriak [8]. 
Nerea Bilbao-Aldaiturriaga, Ángela Gutierrez-Camino, África GarcíaOrad, Idoia Martin-Guerrero

\subsection{OSarekiko suszeptibilitatearen genetika}

OSaren sorrera gehienetan gaztaroan gertatzeak adierazten du gaixotasun honen jatorrian aldagai genetiko garrantzitsu bat dagoela. Gainera, minibizi heredagarria duten zenbait sindrometan agertzen da OSa maizago: Li-Fraumeni sindromean, erretinoblastoma heredagarrian, RothmundThomson sindromean, Bloom eta Werner-en sindromean eta Diamond Blackfan-en sindromean (1. taula). DNAren konponketan eta mantentzean diharduten geneetan penetrantzia osoa duten mutazioek eragiten dituzte sindrome horiek [9].

Sindromeok nahiko arraroak dira, eta OS-kasu guztien $\% 5$ baino ez dute agertzen [1]. Izan ere, kasu gehienak esporadikoak dira.

Esan bezala, OSa gaztaroan gertatzen den gaixotasuna da; beraz, aldagai genetiko indartsuagoa izan dezake. Halere, oraindik ez da aurkitu gaixotasuna eragin dezakeen generik. Hainbat ikerketak proposatu dute efektu aditiboa eta penetrantzia ez-osoa dituzten aldaera genetikoek dutela eragina OSaren jatorrian [9]; hortaz, aldaera hauen efektu txikien batuketa behar da gaixotasunaren suszeptibilitatean eragiteko.

Nukleotido bakarreko aldaketa —edo single nucleotide polymorphisms (SNP) - aldaera genetikorik arruntenetarikoa da. Genoman alelo txikienaren maiztasuna $\% 1$ baino handiagoa duten 10 milioi SNP daudela jotzen da eta SNP horiek giza genomaren \%90en aldakortasun genetikoa azaltzen dute [9]. SNPek, beren kokapenaren arabera, proteinaren sekuentzian (exoian edo mozte-itsastearen gunean) edo genearen erregulazioan (promotorean, RNA ez-kodetzaileak sortzen diren guneetan — ncRNA - eta UTR eskualdean) izan dezakete eragina.

Aldaera genetiko arruntak minbiziaren suszeptibilitatean eragina izan dezakeela frogatu dute ikerketa lan askok. OSaren kasuan, SNPen inplikazioa ikertzeko estrategia bi erabili dira: gene kandidatuen bilaketaren bidezkoa eta genoma osoaren ikerketaren bidezkoa.

\subsubsection{Gene kandidatuen bidezko azterketa}

Gene kandidatuen estrategiari dagokionez, orain arte OSaren arriskuarekin loturiko eta erreplikatutako SNP bakarrak rs2279744 eta rs1690916 dira, MDM2 genean, eta rs231775, CTLA4 genean. Beraz, hiru SNP horiek dira ezagutzen diren OSaren arriskuaren «markatzaile genetiko» bakarrak. Ondorioz, haien efektua beste kohorte batzuetan aztertzea interesgarria litzateke.

\subsubsection{GWAS azterketak}

Aldaera genetiko arrunten azterketarako bigarren estrategia genoma osoko aldaera genetikoen bilaketa da. Azterketa mota horiei Genome wide 
association study (GWAS) deritze. Orain arte, OSari buruzko GWA azterketa bakarra plazaratu da: 941 OS-kasu eta 3.291 kontrol aztertu ziren. Egileek OSarekiko suszeptibilitatearekin erlazionatutako bi loki berri topatu zituzten. GWA azterketa horren emaitzarik esanguratsuena GRM4 genearen inguruan kokatuta zegoen $\mathrm{SNPa}$ izan zen. Gene hori hartzaile glutamatergiko mota bat da, eta osteoblastoetan (hezurra ekoizten duten zelulak) eta osteoklastoetan (hezurra birxurgatzen duten zelulak) adierazten dela ikusi da [10]; hori dela eta, Sarver et al., GRM4 geneak hezurraren osaketan parte hartu eta prozesu hau arautu dezakeela uste dute [11]. Bigarren emaitza esanguratsua, generik gabeko alde intergenikoan aurkitu zuten azterketaren egileek. Hala ere, SNPen lokietan transkripzio-faktore edo/eta motif arautzaileak lotzen zirela ikusi zuten; horrek adierazten du elementu horiek lokiari lotzeak azalpen funtzionala duela $\left(r^{2}>0,6\right)$. Horrez gain, GWA azterketen 30 emaitza esanguratsuenen artean, zortzi SNP alde intergenikoetan kokatuta zeuden [11].

Laburbilduz, OSaren inguruko ikerketa-lan gehienek gune kodetzaileetan dauden aldaera genetikoak aztertu dituzte batik bat. Alabaina, GWA azterketak agerian jarri duen bezala, azalpen biologikorik ez duten gune ezkodetzaileetan ere aurkitu dira OSarekin lotutako aldaera genetikoak. Zenbait minbiziren GWA azterketetan ere egin da aurkikuntza bera: hau da, emaitza esanguratsuenak gune ez-kodetzaileetan aurkitu ziren; haietatik, $\% 3,3 \mathrm{k}$ aldaketak eragiten zituen proteinetan, \%40 gune intronikoetan zegoen, eta \%44, gune intergenikoetan. Emaitza interesgarri horiek gune ezkodetzaileak minbiziaren garapenean gakoak izan daitezkeela iradokitzen dute [12].

\subsection{Gune ez-kodetzaileak}

2001. urtean, Giza Genoma Proiektuak genomaren behin-behineko mapa plazaratu zuen. Proiektu horretan, giza genoman 20.000-25.000 gene zeudela adierazi zen, hau da genomaren \%1,5 [13] (gainerako genoma DNA zaborra edo ez-funtzionala zela uste zen).

Ondoren, ENCODE (ENcyclopedia Of DNA Elements) proiektuan giza genomaren analisi sakonagoa egin zen. Proiektu honen helburua genomaren elementu funtzional guztiak ezagutzea zen, eta horrek genomako gune guztien transkripto primarioen eta helduen irudi zehatzagoa izatea ahalbidetu zuen [14]. Proiektu horrek, halaber, gutxienez genomaren $\% 80$ proteinarik kodetzen ez duten elementuen tankeran kodetzen zela argitu zuen. Elementu horien \%60 inguru RNA ez-kodetzaileak (ncRNA) dira.

Orokorrean, ncRNAk bi taldetan sailkatzen dira beren tamainaren arabera: ncRNA txikiak, edo miRNAk (18-200 bp), eta ncRNA luzeak (> 200 bp) [15]. Minbiziaren alorrean gehien aztertutako ncRNAk miRNAk dira. 
Nerea Bilbao-Aldaiturriaga, Ángela Gutierrez-Camino, África GarcíaOrad, Idoia Martin-Guerrero

\section{4. miRNAk eta hauek prozesatzen dituzten geneak}

\subsection{1. $\operatorname{miRNAk}$}

miRNAk 18-20 nukleotidoko luzera duten ncRNA txikiak dira, eta genomaren kokaleku ezberdinetatik transkriba daitezke: II RNA polimerasaren bidez transkribatzen dira, eta transkripto primario luzea (edo primiRNA) sortzen da (300-5.000 base pareko (bp) kate bikoitzeko RNA). pri-miRNAek erdigunean eskualde bereizgarri bat dute, 30-40 nukleotidoko RNA-harizpi bikoitzeko (double-stranded RNA, dsRNA) xingola itxura duena, eta, erdigunearen kontrako muturretan, kate bakuneko eskualde bana (single-stranded RNA: ssRNA). Pri-miRNAk nukleoan prozesatzen dira (DROSHA RNAsa-ren eta DGCR8 proteinaren bitartez), dsRNAri lotzeko domeinua dute, eta pri-miRNAren sekuentziak primiRNAren egitura zehazten du.

pri-miRNA, haren prozesamenduaren ostean, dsRNA eta muturreko eskualde xingoladunak dituen molekula bilakatzen da: pre-miRNA (70 nukleotido inguru). Molekula hauek nukleotik zitoplasmara garraiatzen dira Exportina5-en (Xpo-5) [16, 17] eta RAN GTPasaren bitartez. Zitoplasman, Dicer entzimak [18-20], TARBP2rekin batera, pre-miRNAri xingola mozten dio, eta miRNA duplexa sortzen da [21]. miRNA duplexa banatuz, kate bakuneko miRNA heldua eratzen da. Jarraian, miRNA honen kateetako bat RISC proteina-konplexuari (RNA-inducing SIlencing konplexuari) eransten zaio. Konplexu hori, EIF2C1, EIF2C2, SND1, GEMIN3, GEMIN4 proteinek eta CCR-NOT konplexuak [22] osatzen dute. miRNA heldu horiek RISC konplexuaren gainean garraiatzen dira, eta RNA mezulariari (mRNA) lotzen zaizkie. Lotura honen ondorioz, miRNAren erregulazioa gertatzen da [23] (3. irudia).

Itu mezulariaren 3’UTR sekuentzien arteko osagarritasunaren bidez gertatzen da miRNAen bidezko erregulazioa. Lotura horiek miRNAren egitura berezi baten bidez gertatzen dira, seed sekuentziaren bidez, alegia. Seed sekuentzia horrek 7 nukleotido ditu. Lotura horren osagarritasunaren arabera dihardu miRNAk. Lotura hauek guztiz osagarriak direnean itzulpena isilarazten da. Bestalde, osagarritasuna partziala denean, mRNA degradatzen da [25].

miRNAek arautzen dituzten geneak prozesu biologiko anitzetan inplikatuta daude, hala nola zelularen garapenean, desberdintze-prozesuan eta proliferazioan, hematopoiesian, angiogenesian eta apoptosian [26]. miRNAk seed sekuentziaren osagarriak diren mRNA itu asko izan ditzake, seed sekuentzia hau txikia delako. Hori dela eta, miRNA batek gene anitz arautu ditzake, eta, halaber, gene batek miRNA anitz arautu ditzake. 


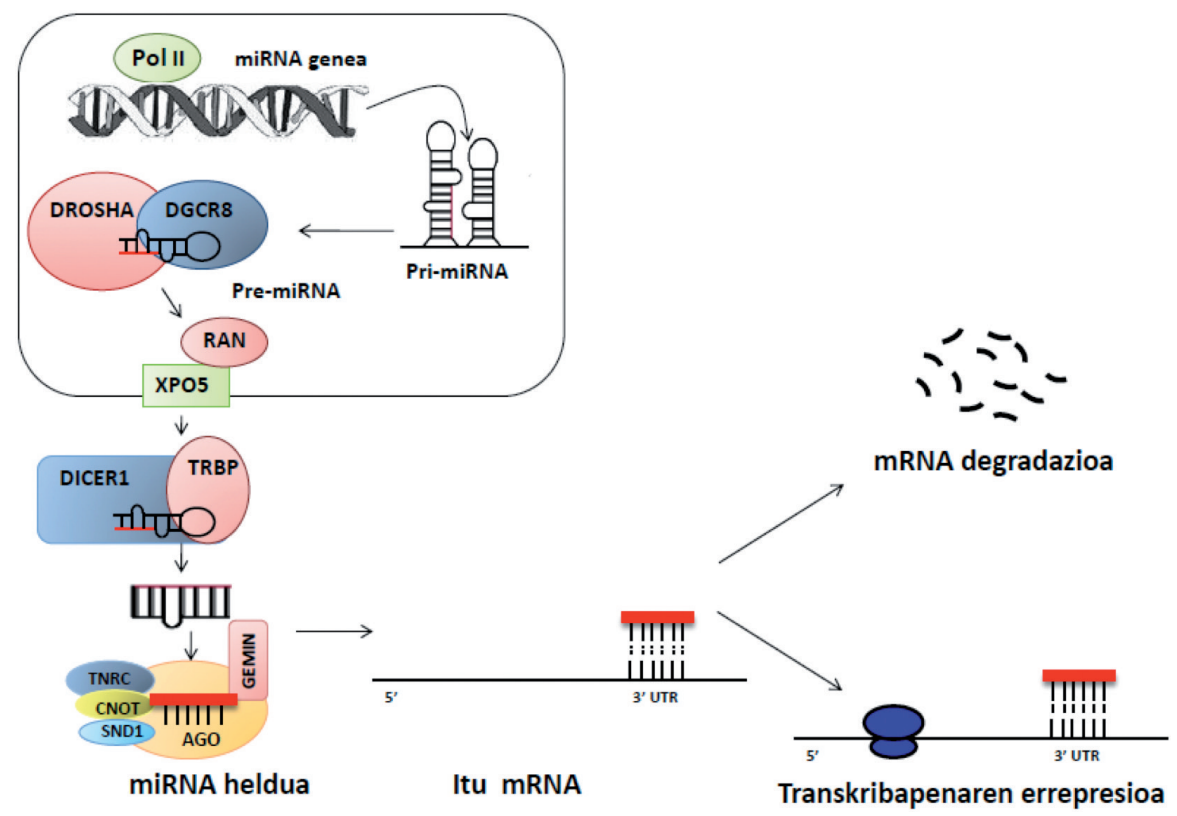

3. irudia. miRNAen sintesiaren eskema orokorra [24]tik moldatua.

\subsection{2. miRNAen prozesamendu-geneak eta minbizia}

Duela gutxi frogatu da miRNAen prozesamenduaren bidezidorreko geneak inplikatuta daudela zelulen eraldatzean eta tumore-genesian [27]. Adibidez, ez dira berdin adierazten minbizian: esate baterako, EIF $2 C 2$ genea (AGO konplexuan) eta TARBP2 genea (DICER konplexuan) gain-adierazita daude prostatako minbizian; DROSHA eta DICER geneak, ostera, azpi-adierazita bularreko minbizian [28]. Gainera, zenbait ikerketa-lanetan ikusi denez, prozesamendu-gene horietan adierazpen-aldaketak gertatzen direnean, aldaketa horiek eragina izaten dute miRNA ekoizpenean [29-32], eta minbizian gertatzen den gene-adierazpena alda dezakete. Ondorioz, miRNAen prozesamendu-geneetan dauden SNPek miRNAen funtzioa alda dezakete. Izan ere, DROSHA genearen rs640831 SNPek 56 miRNAren adierazpena aldatzea eragiten dute birikietako minbizian [33].

Ildo honetan, arestian esan bezala, miRNAen prozesamendu-geneen SNPek miRNAen funtzioen aldaketak eragin ditzakete. Izan ere, prozesamendu-geneetan dauden 7 polimorfismo minbizi mota ezberdinekin erlazionatu dira jadanik (2. taula). 
Nerea Bilbao-Aldaiturriaga, Ángela Gutierrez-Camino, África GarcíaOrad, Idoia Martin-Guerrero

2. taula. miRNAen prozesamendu-geneetan minbiziarekin erlazionatutako SNPak.

\begin{tabular}{c|llc}
\hline Genea & \multicolumn{1}{|c}{ SNP } & \multicolumn{1}{c}{ Gaixotasuna } & Erreferentzia \\
\hline TNRC6B & rs139919 & Leukemia linfoblastiko akutua & {$[34]$} \\
\hline XPO5 & rs11077 & Kartzinoma hepatozelularra & {$[35]$} \\
\hline \multirow{2}{*}{ RAN } & rs14035 & Aho-minbizia & {$[36]$} \\
\hline \multirow{2}{*}{ DGCR8 } & rs636832 & Birikietako minbizia & {$[37]$} \\
\hline \multirow{3}{*}{ GEMIN3 } & rs197409 & Bularreko minbizia & {$[38]$} \\
& rs197414 & Aho-minbizia & {$[40]$} \\
& rs2740348 & Gernu-maskuriko minbizia & {$[40]$} \\
\hline \multirow{3}{*}{ GEMIN4 } & rs7813 & Prostatako minbizia & {$[41]$} \\
\cline { 2 - 4 } & rs7813 & Obarioetako minbizia & {$[42]$} \\
\cline { 2 - 4 } & rs2740351 & Giltzurrunetako minbizia & {$[40]$} \\
& rs7813 & & \\
\hline
\end{tabular}

Nahiz eta jadanik polimorfismoak beste minbizi batzuekin erlazionatu diren, prozesamendu-gene horien polimorfismoek OSan duten papera ez da aztertu oraindik. Hortaz, interes handikoa litzateke aldaera genetiko horiek OSaren jatorrian duten papera argitzea.

\subsection{3. miRNAk eta minbizia}

Gaur egun, jakina da ncRNAek tumore-genesian parte hartzen dutela. Esan bezala, orain arte, ncRNAen artean miRNAk dira minbizian gehien aztertuak. Frogatu da miRNAk ez direla berdin espresatzen tumore-ehunetan eta ehun osasuntsuetan [43-45]; orokorrean, azpi-adierazita daude tumore-ehunetan [46]. Azterketa horiek miRNAk bi taldetan sailkatzea ahalbidetu dute minbizian joka dezaketen funtzioaren arabera: onkomirrak (minbizian gain-adierazita dauden miRNAk) eta miRNA tumore-ezabatzaileak (minbizian azpi-adierazita dauden miRNAk).

Zehatz-mehatz OSan miRNAren adierazpen-sinadurak aurkitu dira, OSaren patogenesiarekin eta progresioarekin erlazionatu direnak [47-49]. Hala ere, miRNAek osteosarkomagenesian duten papera oraindik ez da guztiz ezagutzen. Seiehun miRNA baino gehiagok parte hartzen dute osteogenesiaren erregulazioan; hori dela eta, miRNA horien edozein adierazpen-aldaketak hezur-gaixotasunak eragin ditzakeela uste da [50]. Esate ba- 
terako, mir-34c miRNAen gain-adierazpenak osteoblastoen desberdintzea eta osteoklastogenesia areagotzen du [51]. Beste adibide bat $14 \mathrm{q} 32$ gune kromosomikoan dagoen miRNA-klusterra da, OSaren progresioarekin eta pronostikoarekin erlazionatu dena [52].

Pre-miRNA/miRNAetan dauden SNPek (mir-SNPek) minbizi motetan duten papera asko aztertu da, mir-SNPen bilaketa bibliografikoen eta elkarketa-metaanalisien bitartez. Horietan, mir-146a rs2910164, mir-196a rs11614913, mir-149 rs2292832 eta mir-499 rs3746444, esate baterako, minbizi mota askorekin erlazionatu dira [53, 54].

Orain arte, OSan, mir-SNPen gainean, bi azterketa egin dira, lau mirSNPtan (mir-34b/c, mir-34a, mir-146 eta mir-21); hauetatik, bi SNP mir-34 familiako bi kidetan (mir-34b/c eta mir-34a miRNAetan, hain zuzen ere) OSaren arriskuarekin loturik ikusi zituzten $[55,56]$. Hala ere, nahiz eta mir-SNPen garrantzia frogatu den beste minbizi motetan, oraindik OSan ez dira sakon aztertu.

\section{HELBURUAK}

Tesi-proiektu honen helburu nagusia OS pediatrikoarekiko suszeptibilitatearen markatzaile genetiko berrien bilaketa izan zen.

Horretarako, honako helburu espezifiko hauek ezarri genituen:

1. Literaturan OSarekiko suszeptibilitatearekin loturiko markatzaileen balioztatzea.

a) MDM2 genean dauden rs1690916 eta rs2279744 polimorfismoen eta OSarekiko suszeptibilitatearen erlazioa egiaztatzea, bi populazio berritan kasu-kontrol azterketa eginez, bilaketa sistematikoaren eta metaanalisiaren (MA) bidez.

b) CTLA4 genean dagoen rs231775 polimorfismoaren eta OSarekiko suszeptibilitatearen arteko lotura egiaztatzea, kasu-kontrol azterketaren, bilaketa sistematikoaren eta metaanalisiaren bidez.

2. OSarekiko suszeptibilitateari loturiko adierazpen-aldaketa erakusten duten miRNAen identifikazioa.

a) Literaturaren azterketaren bidez adierazpen-aldaketa duten miRNAen hautaketa.

3. OSarekiko suszeptibilitateari loturiko miRNAekin erlazionatutako geneen aldaera genetikoak zehaztea.

a) miRNAen prozesamendu-geneen aldakortasun genetikoa OSarekiko suszeptibilitatearekin loturik dagoen egiaztatzea eta haien efektu funtzionala aztertzea. 
Nerea Bilbao-Aldaiturriaga, Ángela Gutierrez-Camino, África GarcíaOrad, Idoia Martin-Guerrero

b) pre-miRNAen aldakortasun genetikoa OSarekiko suszeptibilitatearekin loturik dagoen egiaztatzea eta haien efektu funtzionala aztertzea.

\section{METODOAK}

Tesi-proiektu honetan 1076 parte-hartzaile zeuden: 176 gaixo eta 900 kontrol. Pazienteen laginak lau ospitaletatik lortu genituen: Nafarroako Unibertsitatea Klinikatik (104 gaixo), Madrilgo La Paz Ospitaletik (9 gaixo), Donostiako Unibertsitate Ospitaletik (4 gaixo) eta Esloveniako «University Children's Hospital»eko onkologia pediatrikotik (247 gaixo). OS-kasu guztiak patologo eta onkologo adituek diagnostikatu zituzten 1985etik 2013ra bitartean. Kontrolak emaile boluntarioak ziren eta ez zuten erlaziorik gaixoekin. Adingabeko parte-hartzaileen kasuan, gurasoek baimen informatua sinatu behar izan zuten. Lagin guztiak kodifikatu ziren eta Helsinki-ko Hitzarmenaren xehetasunekin bat zetozen Proiektu hau Etika Batzordeak onartu zuten (105/2009 eta 67/02/12). Parte-hartzaile guztien adinari eta sexuari buruzko datuak jaso ziren.

\subsection{OSri loturiko SNPen azterketa}

Lehenik eta behin, OSarekiko suszeptibilitatean eragina zuten aldaera genetikoekin zerikusia zuten lanak bilatu genituen Pubmed datu-basean, polymorphisms $\mathrm{OR}$ «genetic variant» $\mathrm{AND}$ osteosarcoma $\mathrm{OR}$ «bone tumor» terminoekin, 2013. urteko azaroaren 21era arte. Bilaketa honen ostean, MDM2 geneko rs1690916 eta rs2279744 SNPak eta CTLA4 geneko rs231775 SNPak hautatu genituen balioztatzerako, literaturan hiru SNP horiek elkarturik topatu genituelako birritan gutxienez.

\subsubsection{MDM2 genearen rs1690916 SNParen genotipazioa ARMS-PCR bidez}

«Amplification Refractory Mutation System-Polymerase chain reaction» (ARMS-PCR) teknika nukleotido bateko edo delezio txikiko polimorfismoak detektatzeko erabili ohi da. Funtsean, SNP edo delezioaren aleloak detektatzeko hasle bikote bi diseinatzean datza. Hasle pare bakoitzak, alelo bakoitzak sortzen duen sekuentzian oinarrituz diseinatzen denez, alelo hori detektatzen du. Beraz, hasle pare bakoitza aleloarekiko espezifikoa da. Teknika honen azalpena 4. irudian adierazten da. 


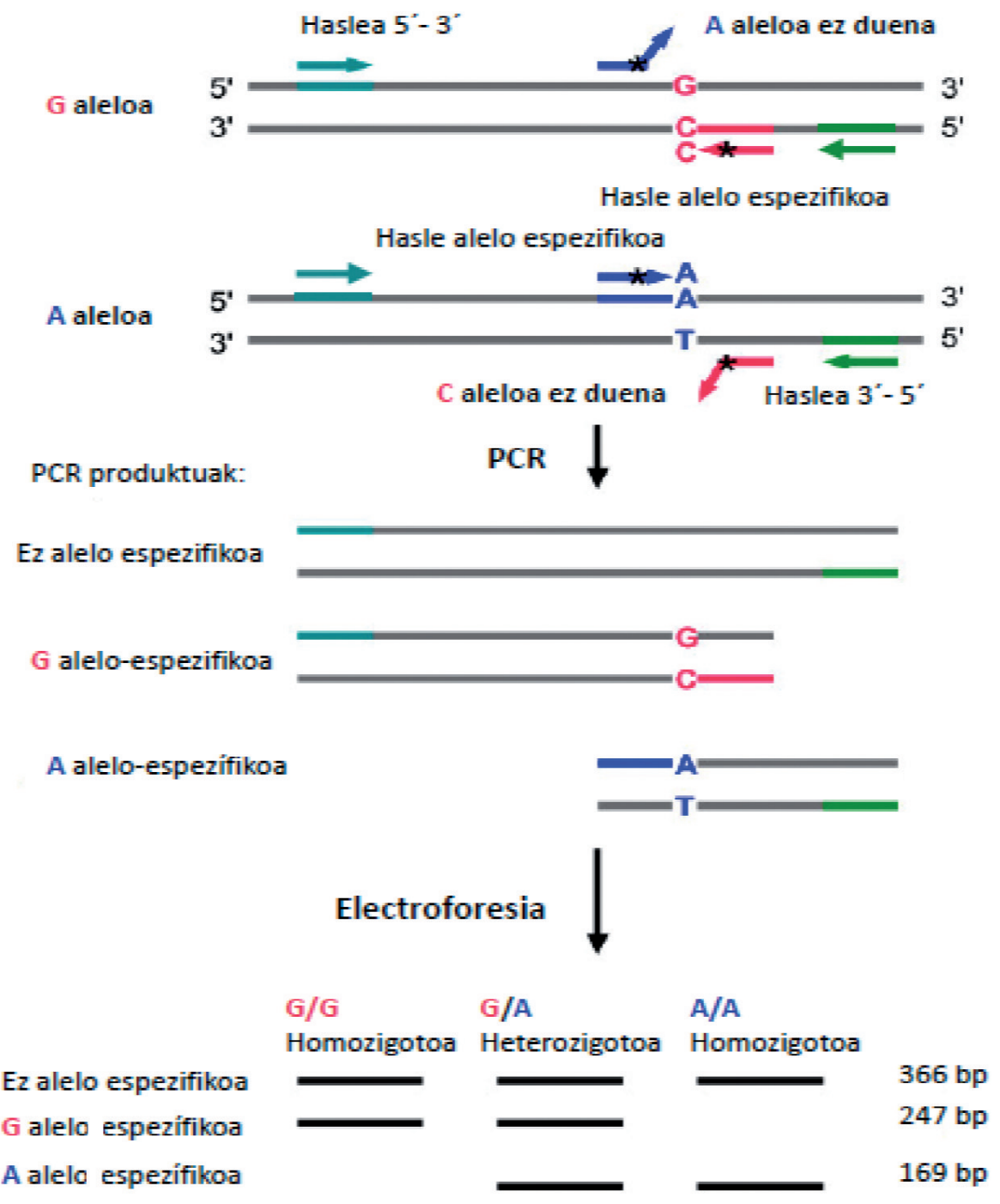

4. irudia. ARMS-PCRa rs 1690916 SNParen aleloen determinaziorako.

Hasle bikoteak rs1690916 SNPa dagoen kokalekuan gainezartzeko diseinatzen dira, hasle bikote bakoitza espezifikoki bere aleloarekin elkartuz. Hasle bikote bakoitzean, hasle batek (Forward edo F) 5'-3' norazkoa du, eta besteak (Reverse edo R) 3'-5' norazkoa. Gainera, hasle bikote bakoitzaren PCR anplifikatuak tamaina-ezberdintasun nabaria izateko diseinatzen dira. Beraz, anplifikatutako produktua bi bandaz osatuta dago: bata ez 
Nerea Bilbao-Aldaiturriaga, Ángela Gutierrez-Camino, África GarcíaOrad, Idoia Martin-Guerrero

da aleloarekiko espezifikoa; bestea, ordea, bai, eta beraz, aleloa determinatuko du.

$\mathrm{G}$ alelorako homozigotoek bi banda sortzen zituzten: 247 bp eta 366 bp (5. irudian 2. kalea); A alelorako homozigotoek bi banda sortzen zituzten: 169 eta 366 bp (5. irudian 2. kalea) eta heterozigotoek hiru banda sortzen zituzten: 169, 247 y 366 bp (5. irudian 3. kalea). Banden adierazpena 5. irudian dira ikusgai.

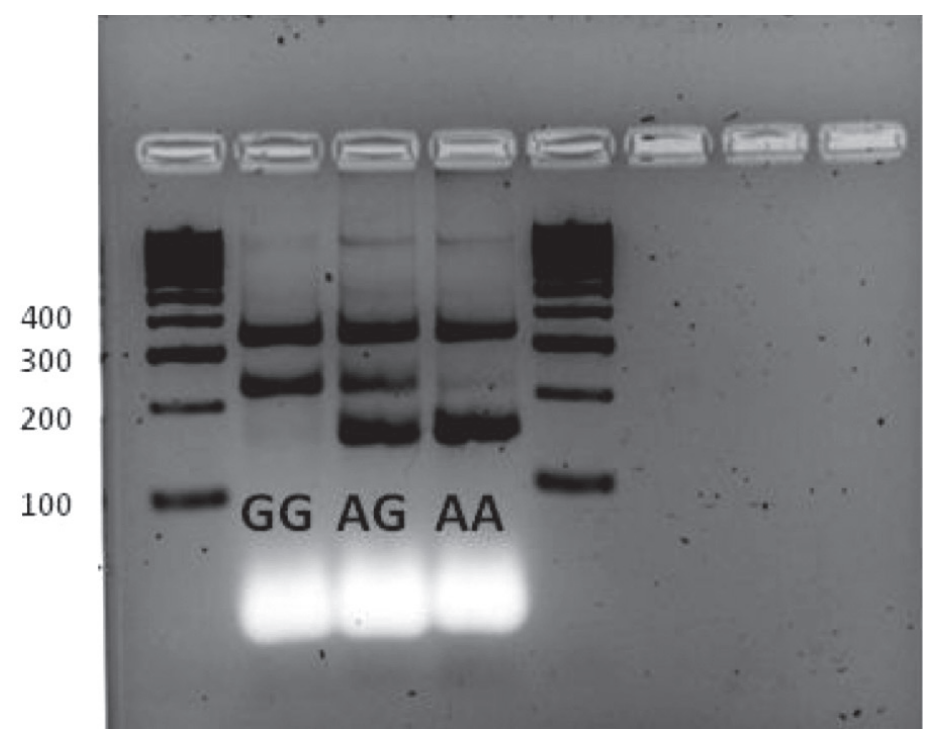

5. irudia. rs1690916 genotipazioaren emaitzak agarosazko gelan.

\subsection{2. rs2279744 SNPAren genotipazioa MDM2 genean PCR-RFLP bidez}

«Polymerase chain reaction-restriction fragment length polymorphism» (PCR-RFLP) teknikak PCR bidezko DNA-anplifikazioa eta errestrikzioentzimen erabilera konbinatzen ditu. rs2279744 SNPAren genotipazioa MDM2 genean PCR-RFLP bidez egin genuen. Teknika honen bidez, SNPa dagoen DNA zatia anplifikatzen da, eta errestrikzio-entzimek SNPa dagoen kokapena mozten dute aleloaren arabera. Horrela, luzera ezberdineko zatiak ikusten dira, eta luzera ezberdinak genotipoa determinatzea ahalbidetzen du. SNP honen aleloa rs1690916 SNParena bezala detektatzen da.

PCR anplifikazio egokia konprobatu genuen \%2ko agarosazko gelan. Ondoren, PCR anplifikatua MspAlI errestrikzio-entzimarekin gau oso batez $37^{\circ} \mathrm{C}$-an inkubatu genuen. Errestrikzio-entzima honek $5^{\prime}-\mathrm{C}(\mathrm{A} / \mathrm{C})$ G'C(G/T)G-3' sekuentzia ezagutzen du espezifikoki; horretan, rs2279744 
bosgarren posizioan dago. $\mathrm{G}$ alelorako homozigotoek hiru zati sortzen zituzten: 31 bp, 46 bp eta $187 \mathrm{bp}$; heterozigotoek lau zati sortzen zituzten: 31 bp, 46 bp, 187 bp eta 233 bp eta T alelorako homozigotoek bi zati sortzen zituzten: 31 bp eta 233 bp.

Errestrikzio-entzima NEBcutter v2.0 softwarea (http://tools.neb.com/ NEBcutter2/) (New England Biolabs) erabiliz aukeratu zen. Bai PCRaren produktuaren bai digestio osteko produktuen elektroforesia \%2ko agarosazko gelen bitartez egin zen, TBE 1X buffer-arekin eta SYBR Safe-ekin tindatuz 30 minutuan 90 volt tentsio konstantean. Lagin bakoitza gelean kargatzeko, $6 \mu 1$ anplifikatu, eta $4 \mu 1$ karga soluzioa erabili genuen. DNA zatien tamaina determinatzeko, Hyperladder IV (100-1.000 pb) markatzaile molekularra erabili genuen. Geletako emaitzak argi ultramorean ikusi genituen Biorad etxeko ChemiDoc XRS dokumentazio-ekipamenduarekin.

Ondoren, MDM2 genearen bi SNP hauen metaanalisia egin genuen eta emaitzak Ekaia aldizkarian argitaratu ziren [59].

\subsubsection{CTLA4 genearen rs231775 SNParen metaanalisia}

CTLA4 genearen rs231775 SNParen eta OSaren arteko erlazioa aztertzen zuten artikuluak aurkitzeko, bilaketa sistematikoa eta metaanalisia egin genituen, MDM2 genearen SNPen azterketaren metodoari jarraituz.

Kasu honetan, bilaketa-estrategia honako hauek izan ziren:

1. («bone tumor» or osteosarcoma) and (polymorphism or SNP).

2. $\mathrm{rs} 231775 \mathrm{OR}+49 \mathrm{G}>\mathrm{A}$.

3. (CTLA4 or «cytotoxic T-lymphocyte-associated protein 4») and («bone tumor» or osteosarcoma).

Gure bilaketak 2014ko martxoaren 25era arte argitaratuta zeuden erregistro guztiak hartu zituen kontuan.

Ondoren, gure azterketako datuak eta bilaketa sistematikoan topatutako artikuluak meta-analisian erabili genituen. rs231775 SNPren OSaren arteko elkarketa AA vs GG + GA-ren bidez eta eredu alelikoarekin (A vs G) balioztatu genuen.

\section{2. miRNAekin erlazionatutako SNPen azterketa}

\subsection{1. miRNAren prozesamendu-geneen SNPen azterketa}

miRNAren prozesamenduan parte hartzen duten gene guztiak aukeratu ziren, 21 gene guztira. Bibliografiaren azterketa sakona egin genuen «microRNA-machinery genes» OR «microRNA Biosynthesis Pathways» terminoekin; zenbait berrikuspen bildu genituen artikuluetatik [23, 57]. 
Nerea Bilbao-Aldaiturriaga, Ángela Gutierrez-Camino, África GarcíaOrad, Idoia Martin-Guerrero

Hogeita bat gene horietan, 72 SNP hautatu ziren, honako irizpide hauei jarraituz. (a) r2 > 0,8 duten tagSNPak aukeratu ziren, hautatutako gene guztien aldakortasun genetikoa kontuan izateko; TagSNPak aukeratzeko, nazioarteko HapMap proiektuaren datu-basea (24. bertsioa; http://www. hapmap.org) eta Haploview softwarea (4.2 bertsioa; http://www.broad. mit.edu/mpg/haploview/) (Broad Institute, Cambridge, USA) erabili ziren. (b) Efektu funtzional potentziala zuten SNPak aukeratu genituen: aminoazido-aldaketa, aldizkako mozte-itsastea, geneen promotorean dauden transkripzio-faktoreen lotura-unean kokatuta zeuden SNPak eta miRNAen itua sortu/ezabatzen dituzten SNPak; SNPen efektu funtzionala, F-SNP (http:// compbio.cs.queensu.ca/F-SNP/) (Queen'sUniversity, Kingston, Canada), FastSNP (http://fastsnp.ibms.sinica.edu.tw) (Academia Sinica, Taipei, Taiwan) eta Patrocles (http://www.patrocles.org/) (University of Liège, Belgium) datu-baseen bidez aztertu genuen. (c) Horrez gain, bibliografian minbiziarekin erlazionaturiko SNPak ere hautatu genituen.

Aukeratutako SNPek \%5 baino handiagoa zuten alelo minimoaren maiztasuna (MAF $\geq 0,05)$ populazio europar eta kaukasoarrean.

\subsection{2. miRNAen prozesamendu-geneen SNPen genotipazioa}

miRNAen prozesamendu-geneen genotipazioa, Euskal Herriko Unibertsitateko (UPV/EHU) Zerbitzu Orokorretan (SGIKER) egin genuen Taqman Open Array teknologiaren bitartez, Applied Biosystems (Foster City, CA) etxeak ematen dituen argibideei jarraituz.

\section{3. miRNA geneen SNPen azterketa}

Ez zen ikerketa-lanik aurkitu miRNAen adierazpen-aldaketak OS pediatrikoarekiko suszeptibilitatean aztertuak zituenik. Beraz, pre-miRNA guztien aldakortasun genetikoa aztertu zen, honako hau kontuan izanda:

1. pre-miRNAen seed gunean dauden SNPek miRNA-mRNA elkarrekintza desoreka dezakete, edota miRNAen itu-geneak aldatu.

2. pre-miRNAetan dauden SNPek bere prozesamenduan eragina izan dezakete, edota miRNA-mRNA elkarrekintza desorekatu ere bai [58]

3. miRNAek gene kopuru handia erregula dezakete, eta, ondorioz, OS pediatrikoaren arriskuan parte hartzen duten geneen erregulazioan inplikatuta egon daitezke miRNAk.

4. pre-miRNA guztietan dauden SNPen kopurua (MAF \%1 baino handiagoa).

Deskribatutako pre-miRNA guztiak miRBase datu-basetik lortu genituen (http://www.mirbase.org/) (bilaketaren amaiera-data: $2013 \mathrm{ko}$ 
martxoa), eta miRNA SNIPER datu-basearen bitartez (http://www. integratomics-time.com/miRNAs-SNIPER/), pre-miRNA guztietatik polimorfikoak zirenak aukeratu genituen. Ondoren, SNP guztiak dbSNP datu-basean (http://www.ncbi.nlm.nih.gov/snp/) bilatu genituen MAFa topatzeko. Populazio kaukasoarrean \%1 etik gorako MAFa (MAF > 0,01) zuten SNPak aukeratu genituen.

\subsection{1. pre-miRNA geneen SNPen genotipazioa}

pre-miRNAetan dauden SNPen genotipaziorako, pre-miRNAetan dauden SNPen genotipazioa Centro Nacional de Genotipado-n (CeGenISCIII) egin zen, llumina etxeko VeraCode-ko GoldenGate teknologia erabiliz. Plataforma honek PCR multiplex entseguak egitea ahalbidetzen du. PCR multiplex bidez, SNP kopuru handia prozesa daiteke aldi berean (1.536 baino gehiago); hori dela eta, denbora, erreaktibo kopurua eta prozesurako beharrezko materialen kopurua murrizten dira.

Genotipatutako SNPen asoziazio-analisien p balioen zuzenketarako metodoen bidez aztertu genituen, alderaketa anitzek positibo faltsuak ematen baitituzte. Zuzenketa-metodoak bi izan ziren: Bonferroni-ren metodoa eta False discovery rate metodoa (FDR).

\section{EMAITZAK}

\subsection{MDM2 genearen rs1690916 eta rs2279744 SNPek OSarekiko suszeptibilitatearekin duten erlazioaren analisia eta metaanalisia}

Laburbilduz, ez zen elkarketa esanguratsurik aurkitu MDM2 genearen rs1690916 eta rs2279744 SNPen eta OS-arriskuaren artean. Emaitza hori kontraesanean zegoen literaturan jasotako datuekin, eta bai SNP hauek aztertzen zituen metaanalisi batekin ere bai.

Hori dela eta, MDM2 genearen polimorfismo horiek eta OS-arriskua aztergai zituzten artikuluen irakurketa kritikoa egitea erabaki genuen, eta baita azterketa hauekin eta genotipatutako populazioekin metaanalisi berria egitea ere. Arestian esan bezala, atal honetako emaitzak Ekaia aldizkarian argitaratu ziren. [59]

\subsection{CTLA4 genearen rs231775 SNParen eta OSarekiko suszeptibilitatearen elkarketaren analisia}

CTLA4 genearen rs231775 SNParen elkarketa hau ez zen adierazgarria izan espainiar populazioan, frekuentzia alelikoen bitartez kalkulatu zenean $(p>0,05)$ (3. taula). 
Nerea Bilbao-Aldaiturriaga, Ángela Gutierrez-Camino, África GarcíaOrad, Idoia Martin-Guerrero

3. taula. CTLA4 genearen rs 231775 polimorfismoaren eta OS-arriskuaren arteko elkarketaren alelo-maiztasun bidezko analisiaren emaitzak.

\begin{tabular}{|c|c|c|c|c|c|c|}
\hline $\mathrm{AM}$ & MAF & Aleloak & $\mathrm{N}(\%)$ kontrolak & $\mathrm{N}(\%)$ kasuak & OR (\%95 KT) & $\mathrm{P}$ \\
\hline \multirow{3}{*}{$\mathrm{G}$} & \multirow{3}{*}{0,38} & G & $93(37,2)$ & $40(30,3)$ & \multirow{3}{*}{ A $1,36(0,87-2,02)$} & \multirow{3}{*}{0,21} \\
\hline & & $\mathrm{A}$ & $157(62,8)$ & $93(70,5)$ & & \\
\hline & & Totala & $250(100)$ & $132(100)$ & & \\
\hline
\end{tabular}

Laburdurak: AM, kontrolen maiztasun txikiena duen aleloa; MAF, alelo txikienaren maiztasuna; OR, Odds Ratio; KT, konfiantza-tartea.

Ondoren, bilaketa bibliografikoa eta, fase horretan lortutako argitalpen guztiekin, metaanalisia egin genuen.

\subsection{1. rs231775 SNParen metaanalisia}

rs231775 SNParen metaanalisian, Txinako bi populazio eta guk genotipatutako espainiar populazioa erabili genituen. Genotipoen banaketak, kontroletan, Hardy-Weinberg-en orekari (HW oreka) jarraitzen zion $(p>0,05)$. Artikulu guztiek kalitate-eskala gainditu zuten ( $>5$ balioa).

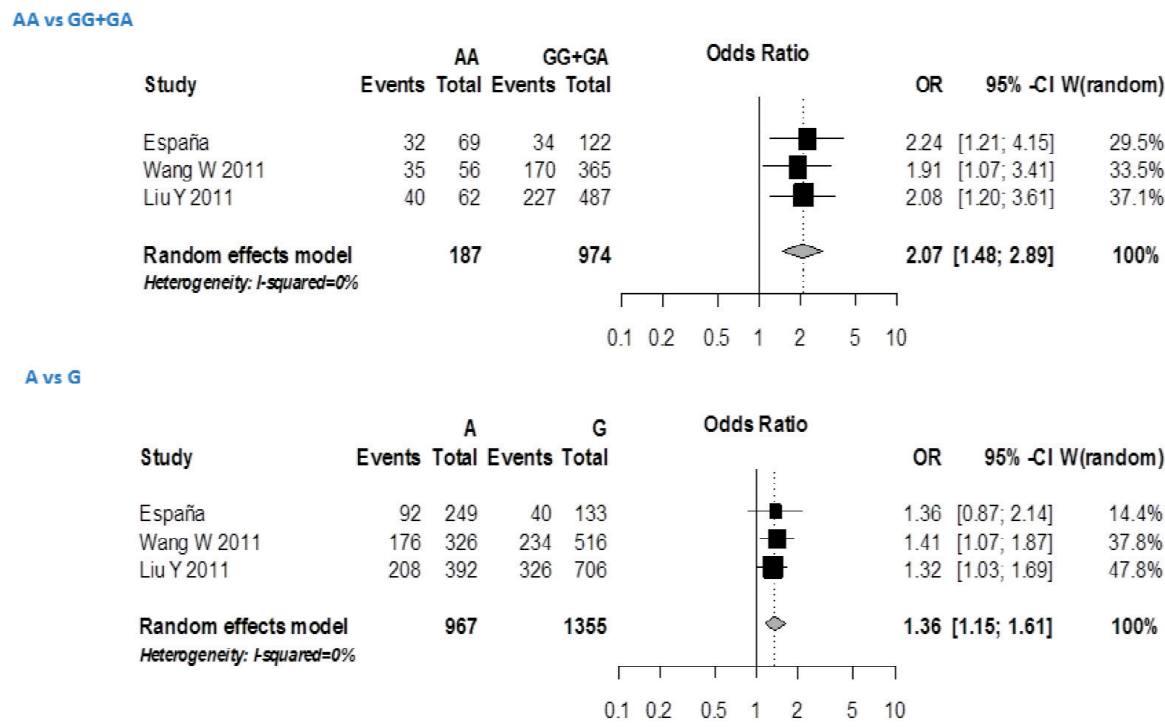

6. irudia. rs231775 polimorfismoaren metaanalisia.

Metaanalisiaren emaitzak agerian utzi zuen AA genotipoak OS-arriskua areagotzen zuela OS (OR = 2,07, \%95eko KT, 1,48-2,89). Era berean, 
A aleloak ere areagotzen zuen arriskua (OR = 1,36, \%95eko KT 1,15-1,61) (6. irudia).

\section{3. miRNAekin erlazionatutako geneen SNPen azterketa}

OSarekiko suszeptibilitatean inplikatuta dauden miRNAk determinatzeko helburuan, bilaketa bibliografiko sakona egin genuen OSaren adierazpena aldatuta daukaten miRNAk aurkitzeko. OSarekiko suszeptibilitatearen arriskuaren adierazle zen miRNArik ez genuenez topatu, miRNAekin erlazionatutako gene guztien aldakortasun genetikoa aztertzea erabaki genuen, hau da, miRNA prozesamenduan diharduten geneen zein miRNA geneen aldakortasuna.

\subsection{1. miRNAen prozesamendu-geneen SNPen azterketa}

miRNAren prozesamendu-geneen aldakortasun genetikoek OS-arriskuan eragina zuten aztertzeko, maiztasun alelikoak zein maiztasun genotipikoak 21 genetako 57 polimorfismoetan analizatu genituen. Hiru polimorfismo hiru prozesamendu-genetan (CNOT1, CNOT4 eta SND1) OS-arriskuarekin elkarturik zeuden $(p<0,05)$.

rs11866002 SNPa izan zen elkarketarik adierazgarriena. Eredu dominantean, CT + TT genotipoa OSarekiko suszeptibilitatearen arriskuaren murrizketarekin (OR =0,44; \%95eko KT: 0,27-0,73; $p=0,001)$ erlazionatu zen. Azpimarratzekoa da Bonferroniren zuzenketaren ostean ere adierazgarri mantendu zela $(p=0,08)$. Konparazio anitzak (kasu honetan, SNP asko ditugulako) egiten direnean, $\mathrm{p}$ balioak benetan baino adierazgarriagoak suerta daitezke eta Bonferroniren zuzenketak konparazio anitz horiek modu kontserbadoreagoan kalkulatzen ditu. Halaber, rs3812265 SNPa, CNOT4 genean ( $p=0,025$; eredu dominantean), eta rs3823994 SNPa, SND1 genean ( $p=0,041$, eredu aditiboan), OS-arriskuarekin erlazionatuta zeuden (Bonferroniren zuzenketaren aurretik).

\subsection{2. miRNA-geneetan dauden SNPen azterketa}

miRNA-geneetan dauden polimorfismoak geneen funtzioan izan dezakete eragina, eta ondorioz, OSarekiko suszeptibilitatean eragina izan dezaketen miRNA-mailak alda daitezke. miRNA polimorfismoek OS-arriskuan eragina zuten ala ez zehazteko, 213 polimorfismo aztertu genituen 206 miRNA-genetan.

Maiztasun genotipikoen bidezko elkarketa-analisian, 14 miRNAtan kokaturik zeuden 14 polimorfismo topatu genituen OS arriskuarekin elkarturik $(p<0,05)$. Azpimarragarria da SNP horietako lau 14q32 gune kromosomikoan kokatuta zeudela. Polimorfismo adierazgarri guztiak 
Nerea Bilbao-Aldaiturriaga, Ángela Gutierrez-Camino, África GarcíaOrad, Idoia Martin-Guerrero

pre-miRNAn kokatuta zeuden, baina rs35770269 mir-449c, miRNAren seed gunean. FDR bidezko zuzenketaren ostean ez zen SNP adierazgarririk azaldu.

\section{EZTABAIDA}

Tesi-proiektu honen helburu nagusia OS pediatrikoen arriskuaren markatzaile genetiko berrien bilaketa izan zen. Horretarako, lehendabizi, literaturan bilaketa bibliografikoa egin genuen OSarekiko suszeptibilitatearekin erlazionaturik zeuden markatzaile genetikoak ezartzeko. Bilaketa honetan, aztertutako aldaera genetiko guztietatik $(n=5250 \mathrm{SNP})$, hiru SNPk erakusten zuten soilik OS-arriskuarekiko erlazio sendoa (hau da, erlazionatutako eta balioztatutako SNP bakarrak): rs1690916 eta rs2279744, MDM2 genean, eta rs231775, CTLA4 genean. Hori dela eta, emaitza horiek balioztatzeko helburua genuen. MDM2 genearen polimorfismoei dagokienez, ez genuen OS-arriskuarekiko erlazio adierazgarririk aurkitu, ez elkarketa-analisian ez populazio guztiekin egindako metaanalisian. Horrez gain, gure metaanalisian jasotako emaitza kontraesanean zegoen gure helburu bera zuen beste metaanalisi batekin. Argitaratutako metaanalisi horren berrikuspena egin ondoren, bai Liu et al-en taldeak [60] bai gure taldeak Wang et al.-en metaanalisian zenbait akats atzeman genituen.

CTLA4 genean dagoen rs231775, ordea, bazegoen OS-arriskuarekin erlazionaturik Espainiako populazioan. Emaitza hauek, beraz, adierazten dute CTLA4 genean dagoen rs231775 SNPa izan daitekeela OSarekiko suszeptibilitatearen markatzaile genetiko bakarra. Gene kodetzaileen aldaera genetikoen ikerketen emaitza urriak zirela eta, gene ez-kodetzaileen (zehazki, miRNAen) aldakortasun genetikoa aztertzea erabaki genuen. Horretarako, alde batetik, miRNAen prozesamendu-geneak eta, bestetik, miRNAen polimorfismoak aztertu genituen. miRNA-prozesamenduei dagokiela, OS-arriskuarekin elkarturiko hiru SNP aurkitu genituen RISC konplexuan; CNOT1, CNOT4 eta SND1 geneetan, hain zuzen ere [61].

Estreinakoz aztertu dira hain sakonki pre-miRNA SNPak OSarekiko suszeptibilitatean. Azterketa honetan, 26 SNP atzeman genituen, 25 miRNA genetan, OSarekiko suszeptibilitatearekin erlazionatuak. Gure emaitzarik interesgarriena 14q32 miRNA-klusterrean lortu zen: horretan, 4 miRNAtan dauden 4 SNPek asoziazio adierazgarria izan zuten espainiar populazioan. miRNA-kluster horretako miRNAek $M Y C$ genea erregulatzen dute OSan. MYC genearen aktibazioak OSaren patogenesian paper garrantzitsua jokatzen du; izan ere, gene hori inplikatuta dago hezur-muineko estroman kokatuta dauden zelulen transformazio-prozesuan (OS-ze- 
luletara) [62]. Horrez gain, Thayanithy eta kolaboratzaileek erakutsi zuten miRNA horiek tumorigenesian parte hartzen zutela; izan ere, blokeatzen badira, osteoblastoen ahalmen proliferatiboa, migratzailea eta inbasiboa areagotzen dira. Hori dela eta, OSrekiko suszeptibilitatearen hotspot-a izan daitezke.

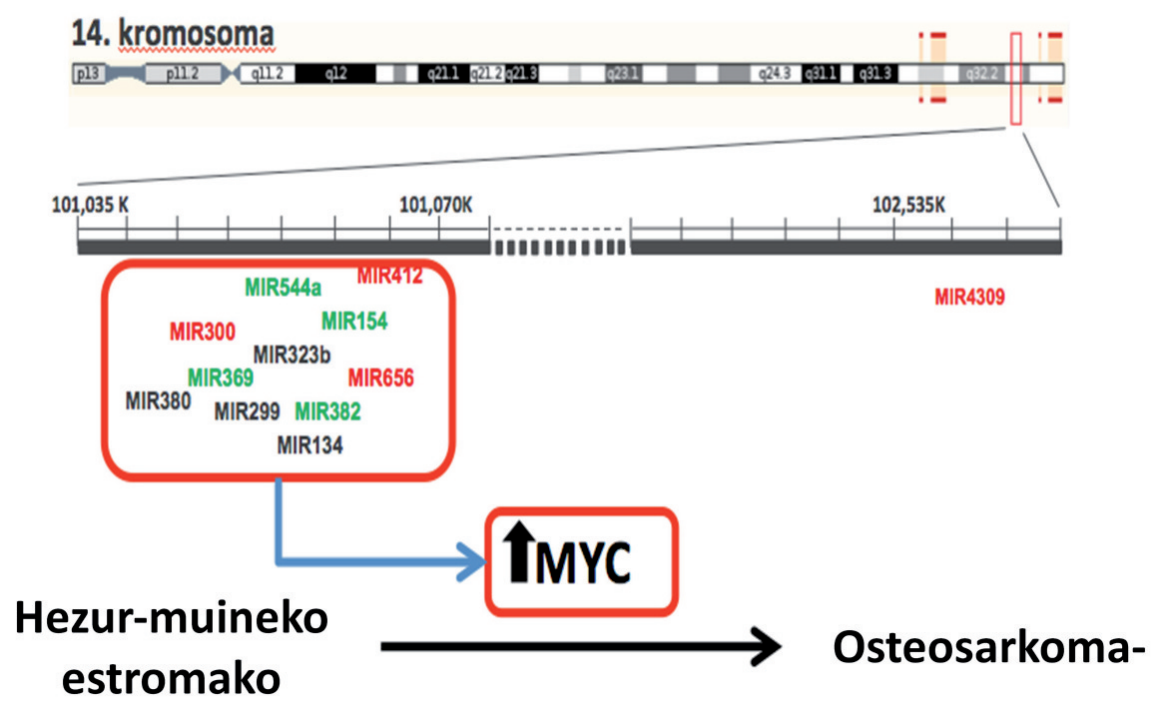

7. irudia. $14 \mathrm{q} 32$ miRNA-klusterrean aurkitutako miRNAen kokapena genoman. Berdez, osteosarkoman gain-adierazita dauden miRNAk, eta gorriz, azpi-adierazita dauden miRNAk.

Esloveniako populazioan, aldiz, 16q24 gune kromosomikoan atzeman genuen mir-SNPik adierazgarriena. 16q24 gunean SNPak material genetikoaren delezioa zegoela adierazten zigun. Espainiako eta Eslovakiako populazioak batera aztertu genituenean, ahalmen estatistikoa emendatu genuen, eta hiru arrisku-markatzaile berri atzeman genituen: mir-146a, mir-4752 eta mir-6128. Emaitza horien arabera, miRNAren hiru polimorfismo hauek OSarekiko suszeptibilitatearen markatzaile moduan joka dezakete populazio orokorrean.

\section{AZKEN HAUSNARKETAK}

MDM2 genearen rs1690916 eta rs2279744 polimorfismoek OSarekiko suszeptibilitatearekin duten erlazioa aztertu eta gero, ez genuen haien ar- 
Nerea Bilbao-Aldaiturriaga, Ángela Gutierrez-Camino, África GarcíaOrad, Idoia Martin-Guerrero

teko loturarik aurkitu. Hortaz, aldaera horiek ez lirateke OSarekiko suszeptibilitatearen markatzailetzat jo behar.

1. CTLA4 genearen rs 231775 polimorfismoaren kasuan, literaturan ikusitako emaitzak baieztatu genituen. Hortaz, CTLA4 genearen rs231775 polimorfismoa OSarekiko suszeptibilitatearen markatzailea izan daiteke.

2. Gure emaitzek RISC konplexuak minbizian duen garrantzia azpimarratzen dute. Izan ere, hiru aldaera genetiko aurkitu genituen OSarekiko suszeptibilitatearekin erlazionatuak konplexu horren hiru genetan (rs11866002, CNOT1 genean; rs3812265, CNOT4 genean, eta rs3823994, SND1 genean) .

3. 14q32 gune kromosomikoa OSarekiko suszeptibilitatearen hostspot-a izan daiteke. Gune horretan, izan ere, MYC onkogenea erregulatzen duten miRNA-klusterreko aldaera genetikoek onkogenearen funtzioa alda dezakete.

Ondorioz, gure emaitzek gune ez-kodetzaileetako aldaera genetikoek OS pediatrikoarekiko suszeptibilitatean duten garrantzia azpimarratzen ditutze.

\section{BIBLIOGRAFIA}

[1] KENT PM, TRAFTON LW. Clinical presentation of bone tumors in children and young adults. Curr Probl Cancer. 2013;37(4):167-71.

[2] FLETCHER CDM, UNNI KK, MERTENS F, World Health Organization., International Agency for Research on Cancer. Pathology and genetics of tumours of soft tissue and bone. Lyon: IARC Press; 2002. 427 p. p.

[3] ROSENBERG AE, CLETON-JANSEN AM, DE PINIEUX G, DEYRUP AT, HAUBEN E, SQUIRE J. The World Health Organization classification of tumors of soft tissue and bone tumors. Fletcher CDM, Hogendoorn PCW, Mertens F, Bridge J, editors2013.

[4] GENG S, ZHANG X, CHEN J, LIU X, ZHANG H, XU X, et al. The tumor suppressor role of miR-124 in osteosarcoma. PLoS One. 2014;9(6):e91566.

[5] MOHSENY AB, HOGENDOORN PC. Concise review: mesenchymal tumors: when stem cells go mad. Stem Cells. 2011;29(3):397-403.

[6] TANG N, SONG WX, LUO J, HAYDON RC, HE TC. Osteosarcoma development and stem cell differentiation. Clin Orthop Relat Res. 2008;466(9):2114-30.

[7] VISVADER JE. Cells of origin in cancer. Nature. 2011;469(7330):314-22.

[8] MUTSAERS AJ, WALKLEY CR. Cells of origin in osteosarcoma: mesenchymal stem cells or osteoblast committed cells? Bone. 2014;62:56-63. 
[9] SAVAGE SA, MIRABELLO L. Using epidemiology and genomics to understand osteosarcoma etiology. Sarcoma. 2011;2011:548151.

[10] SKERRY TM. The role of glutamate in the regulation of bone mass and architecture. J Musculoskelet Neuronal Interact. 2008;8(2):166-73.

[11] SAVAGE SA, MIRABELLO L, WANG Z, GASTIER-FOSTER JM, GORLICK R, KHANNA C, et al. Genome-wide association study identifies two susceptibility loci for osteosarcoma. Nat Genet. 2013;45(7):799-803.

[12] CHEETHAM SW, GRUHL F, MATTICK JS, DINGER ME. Long noncoding RNAs and the genetics of cancer. Br J Cancer. 2013;108(12):2419-25.

[13] MCPHERSON JD, MARRA M, HILLIER L, WATERSTON RH, CHINWALLA A, WALLIS J, et al. A physical map of the human genome. Nature. 2001;409(6822):934-41.

[14] CONSORTIUM IHGS. Finishing the euchromatic sequence of the human genome. Nature. 2004;431(7011):931-45.

[15] SANA J, FALTEJSKOVA P, SVOBODA M, SLABY O. Novel classes of non-coding RNAs and cancer. J Transl Med. 2012;10:103.

[16] BOHNSACK MT, CZAPLINSKI K, GORLICH D. Exportin 5 is a RanGTPdependent dsRNA-binding protein that mediates nuclear export of premiRNAs. RNA. 2004;10(2):185-91.

[17] KIM VN. MicroRNA precursors in motion: exportin-5 mediates their nuclear export. Trends Cell Biol. 2004;14(4):156-9.

[18] HUTVÁGNER G, MCLACHLAN J, PASQUINELLI AE, BÁLINT E, TUSCHL T, ZAMORE PD. A cellular function for the RNA-interference enzyme Dicer in the maturation of the let-7 small temporal RNA. Science. 2001;293(5531):834-8.

[19] KETTING RF, FISCHER SE, BERNSTEIN E, SIJEN T, HANNON GJ, PLASTERK RH. Dicer functions in RNA interference and in synthesis of small RNA involved in developmental timing in C. elegans. Genes Dev. 2001;15(20):2654-9.

[20] MERRITT WM, BAR-ELI M, SOOD AK. The dicey role of Dicer: implications for RNAi therapy. Cancer Res. 2010;70(7):2571-4.

[21] SONG JJ, LIU J, TOLIA NH, SCHNEIDERMAN J, SMITH SK, MARTIENSSEN RA, et al. The crystal structure of the Argonaute2 PAZ domain reveals an RNA binding motif in RNAi effector complexes. Nat Struct Biol. 2003;10(12):1026-32.

[22] INADA T, MAKINO S. Novel roles of the multi-functional CCR4-NOT complex in post-transcriptional regulation. Front Genet. 2014;5:135.

[23] LI S, WANG L, FU B, BERMAN MA, DIALLO A, DORF ME. TRIM65 regulates microRNA activity by ubiquitination of TNRC6. Proc Natl Acad Sci U S A. 2014;111(19):6970-5.

[24] MISHRA PJ AND BERTINO JR. MicroRNA polymorphisms: the future of pharmacogenomics, molecular epidemiology and individualized medicine. Pharmacogenomics. 2009 Mar;10(3):399-416. doi: 10.2217/14622416.10.3.399. 
Nerea Bilbao-Aldaiturriaga, Ángela Gutierrez-Camino, África GarcíaOrad, Idoia Martin-Guerrero

[25] GREGORY RI, CHENDRIMADA TP, SHIEKHATTAR R. MicroRNA biogenesis: isolation and characterization of the microprocessor complex. Methods Mol Biol. 2006;342:33-47.

[26] VAROL N, KONAC E, GUROCAK OS, SOZEN S. The realm of microRNAs in cancers. Mol Biol Rep. 2011;38(2):1079-89.

[27] KUMAR MS, LU J, MERCER KL, GOLUB TR, JACKS T. Impaired microRNA processing enhances cellular transformation and tumorigenesis. Nat Genet. 2007;39(5):673-7.

[28] HUANG JT, WANG J, SRIVASTAVA V, SEN S, LIU SM. MicroRNA Machinery Genes as Novel Biomarkers for Cancer. Front Oncol. 2014;4:113.

[29] MELO SA, ESTELLER M. Disruption of microRNA nuclear transport in human cancer. Semin Cancer Biol. 2014;27C:46-51.

[30] MELO SA, ROPERO S, MOUTINHO C, AALTONEN LA, YAMAMOTO $\mathrm{H}$, CALIN GA, et al. A TARBP2 mutation in human cancer impairs microRNA processing and DICER1 function. Nat Genet. 2009;41(3):365-70.

[31] ILIOU MS, DA SILVA-DIZ V, CARMONA FJ, RAMALHO-CARVALHO J, HEYN H, VILLANUEVA A, ET AL. Impaired DICER1 function promotes stemness and metastasis in colon cancer. Oncogene. 2013.

[32] WU S, YU W, QU X, WANG R, XU J, ZHANG Q, et al. Argonaute 2 promotes myeloma angiogenesis via microRNA dysregulation. J Hematol Oncol. 2014;7(1):40.

[33] ROTUNNO M, ZHAO Y, BERGEN AW, KOSHIOL J, BURDETTE L, RUBAGOTTI M, ET AL. Inherited polymorphisms in the RNA-mediated interference machinery affect microRNA expression and lung cancer survival. Br J Cancer. 2010;103(12):1870-4.

[34] GUTIERREZ-CAMINO A, LOPEZ-LOPEZ E, MARTIN-GUERRERO I, PIÑAN MA, GARCIA-MIGUEL P, SANCHEZ-TOLEDO J, et al. Noncoding RNA-related polymorphisms in pediatric acute lymphoblastic leukemia susceptibility. Pediatr Res. 2014;75(6):767-73.

[35] LIU S, AN J, LIN J, LIU Y, BAO L, ZHANG W, et al. Single nucleotide polymorphisms of microRNA processing machinery genes and outcome of hepatocellular carcinoma. PLoS One. 2014;9(3):e92791.

[36] CHO SH, KO JJ, KIM JO, JEON YJ, YOO JK, OH J, OH D, KIM JW, KIM NK. 3'-UTR Polymorphisms in the MiRNA Machinery Genes DROSHA, DICER1, RAN, and XPO5 Are Associated with Colorectal Cancer Risk in a Korean Population. PLoS One. 2015 Jul 6;10(7):e0131125. doi: 10.1371/ journal.pone.0131125. eCollection 2015.

[37] KIM JS, CHOI YY, JIN G, KANG HG, CHOI JE, JEON HS, et al. Association of a common AGO1 variant with lung cancer risk: a two-stage case-control study. Mol Carcinog. 2010;49(10):913-21.

[38] JIANG Y, CHEN J, WU J, HU Z, QIN Z, LIU X, et al. Evaluation of genetic variants in microRNA biosynthesis genes and risk of breast cancer in Chinese women. Int J Cancer. 2013;133(9):2216-24. 
[39] YANG H, DINNEY CP, YE Y, ZHU Y, GROSSMAN HB, WU X. Evaluation of genetic variants in microRNA-related genes and risk of bladder cancer. Cancer Res. 2008;68(7):2530-7.

[40] HORIKAWA Y, WOOD CG, YANG H, ZHAO H, YE Y, GU J, et al. Single nucleotide polymorphisms of microRNA machinery genes modify the risk of renal cell carcinoma. Clin Cancer Res. 2008;14(23):7956-62.

[41] LIU J, WEI M, HE Y, LIAO B, LIAO G, LI H, et al. Genetic variants in the microRNA machinery gene GEMIN4 are associated with risk of prostate cancer: a case-control study of the Chinese Han population. DNA Cell Biol. 2012;31(7):1296-302.

[42] LIANG D, MEYER L, CHANG DW, LIN J, PU X, YE Y, et al. Genetic variants in MicroRNA biosynthesis pathways and binding sites modify ovarian cancer risk, survival, and treatment response. Cancer Res. 2010;70(23):9765-76.

[43] PALANICHAMY JK, RAO DS. miRNA dysregulation in cancer: towards a mechanistic understanding. Front Genet. 2014;5:54.

[44] DI LEVA G, GAROFALO M, CROCE CM. MicroRNAs in cancer. Annu Rev Pathol. 2014;9:287-314.

[45] KONG YW, FERLAND-MCCOLLOUGH D, JACKSON TJ, BUSHELL M. microRNAs in cancer management. Lancet Oncol. 2012;13(6):e249-58.

[46] LAW PT, WONG N. Emerging roles of microRNA in the intracellular signaling networks of hepatocellular carcinoma. J Gastroenterol Hepatol. 2011;26(3):437-49.

[47] MAIRE G, MARTIN JW, YOSHIMOTO M, CHILTON-MACNEILL S, ZIELENSKA M, SQUIRE JA. Analysis of miRNA-gene expression-genomic profiles reveals complex mechanisms of microRNA deregulation in osteosarcoma. Cancer Genet. 2011;204(3):138-46.

[48] JONES KB, SALAH Z, DEL MARE S, GALASSO M, GAUDIO E, NUOVO GJ, et al. miRNA signatures associate with pathogenesis and progression of osteosarcoma. Cancer Res. 2012;72(7):1865-77.

[49] KOBAYASHI E, HORNICEK FJ, DUAN Z. MicroRNA Involvement in Osteosarcoma. Sarcoma. 2012;2012:359739.

[50] VAN WIJNEN AJ, VAN DE PEPPEL J, VAN LEEUWEN JP, LIAN JB, STEIN GS, WESTENDORF JJ, et al. MicroRNA functions in osteogenesis and dysfunctions in osteoporosis. Curr Osteoporos Rep. 2013;11(2):72-82.

[51] BAE Y, YANG T, ZENG HC, CAMPEAU PM, CHEN Y, BERTIN T, et al. miRNA-34c regulates Notch signaling during bone development. Hum Mol Genet. 2012;21(13):2991-3000.

[52] KELLY AD, HAIBE-KAINS B, JANEWAY KA, HILL KE, HOWE E, GOLDSMITH J, ET AL. MicroRNA paraffin-based studies in osteosarcoma reveal reproducible independent prognostic profiles at 14q32. Genome Med. 2013;5(1):2. 
Nerea Bilbao-Aldaiturriaga, Ángela Gutierrez-Camino, África GarcíaOrad, Idoia Martin-Guerrero

[53] XIA L, REN Y, FANG X, YIN Z, LI X, WU W, et al. Prognostic role of common microRNA polymorphisms in cancers: evidence from a meta-analysis. PLoS One. 2014;9(10):e106799.

[54] SRIVASTAVA K, SRIVASTAVA A. Comprehensive review of genetic association studies and meta-analyses on miRNA polymorphisms and cancer risk. PLoS One. 2012;7(11):e50966.

[55] TIAN Q, JIA J, LING S, LIU Y, YANG S, SHAO Z. A causal role for circulating miR-34b in osteosarcoma. Eur J Surg Oncol. 2014;40(1):67-72.

[56] LV H, PEI J, LIU H, WANG H, LIU J. A polymorphism site in the pre-miR-34a coding region reduces miR-34a expression and promotes osteosarcoma cell proliferation and migration. Mol Med Rep. 2014;10(6):2912-6.

[57] SIMES RJ. Confronting publication bias: a cohort design for meta-analysis. Stat Med. 1987;6(1):11-29.

[58] BREVING K, ESQUELA-KERSCHER A. The complexities of microRNA regulation: mirandering around the rules. Int $\mathrm{J}$ Biochem Cell Biol. 2010;42(8):1316-29.

[59] BILBAO ALDAITURRIAGA, N, MARTIN-GUERRERO, I, GARCÍAORAD CARLES, A. Meta-analisien erabilgarritasunaren analisi kritikoa. Ekaia. Volumen 27. ISSN: 0214-9001.

[60] LIU G, XU W, HAO Y, XU Z. Letter regarding Wang et al. entitled «Effects of murine double minute 2 polymorphisms on the risk and survival of osteosarcoma: a systemic review and meta-analysis». Tumour Biol. 2014;35(4):3943-4.

[61] BILBAO-ALDAITURRIAGA N, GUTIÉRREZ-CAMINO A, MARTINGUERRERO I, POMBAR-GÓMEZ M, ZALACAIN-DÍEZ M, PATIÑOGARCÍA A, LÓPEZ-LÓPEZ E, GARCIA-ORAD A. Polymorphisms in miRNAprocessing genes and their role in osteosarcoma risk. Pediatr Blood Cancer. 2015 May;62(5):766-9.

[62] SHIMIZU T, ISHIKAWA T, SUGIHARA E, KUNINAKA S, MIYAMOTO $\mathrm{T}$, MABUCHI Y, et al. c-MYC overexpression with loss of Ink4a/Arf transforms bone marrow stromal cells into osteosarcoma accompanied by loss of adipogenesis. Oncogene. 2010;29(42):5687-99. 